\title{
JOHN GARSTANG AND SAKÇAGÖZÜ EXCAVATIONS (1908-1911)
}

\section{Ali ÇİFÇ்}

\begin{abstract}
$\ddot{O} z$
John Garstang ve Sakçagözü Kazıları (1908-1911)**

Gaziantep ili Nurdağı ilçesinde bulunan Sakçagözü (Coba Höyük) 1908 ile 1911 yılları arasında John Garstang tarafindan iki kazı sezonu çerçevesinde kazılır. Höyükte yapılan kazılarda 11 tabaka tespit edilmiştir. Bunlardan IX. ve X. tabakalar Geç Hitit saray kompleksinin bulunduğu döneme tarihlendirilmekte. Bu tabakalarda etrafi sur duvarlart ile çevrili bir saray kompleksi ve bu saray yapısının içerisinde rölyefler ile süslü bir 'bit hilani' yapısı ortaya çıkarılmıștır. Bu çalışmada Liverpool Üniversitesi Garstang Arkeoloji Müzesi'nde bulunan ve kazı hafirine ait yazı̧̧malar, kazı fotoğrafları ile İstanbul Arkeoloji Müzesi'nde bulunan kazı malzemesi değerlendirilmektedir. Ayrıca Garstang'ın dönemin Müze-i Hümayun müdürü olan Osman Hamdi Bey ve İstanbul İngiliz konsolosluğu çalışanı Sir Edwin Pears ile olan ilişkisi, Sakçagözü'nde kazı izni alma süreci, kazllarda ortaya çıkarılan Geç Hitit kabartmalarına olan ilgisi çalışma kapsamında araştırma konusu edilmiştir.
\end{abstract}

Anahtar Sözcükler: John Garstang, Sakçagözü, Coba Höyük, Geç Hitit, heykelttraşlık.

\begin{abstract}
Sakçagözü, located in the Nurdağl district of Gaziantep province, was excavated by John Garstang between 1908 and 1911 during two excavation seasons. Of the 11 identified layers, IX. and $X$. contain the Neo-Hittite palace enclosure, which was surrounded by walls and had a 'bit hilani' structure decorated with reliefs. The excavation records, photographs and materials held at the University of Liverpool's Garstang Museum of Archaeology, as well as materials held at the Archaeological Museum of Istanbul were utilised for this study. Garstang's relations with the director of the Imperial Museum Osman Hamdi Bey, and Sir Edwin Pears from the British Consulate in Istanbul at the time, will also be considered. I will also consider how Garstang obtained the excavation permit for the Sakçagözü and his subsequent interest in the Neo-Hittite reliefs found here.
\end{abstract}

Key Words: John Garstang, Sakçagözü, Coba Höyük, Neo-Hittite, reliefs.

\footnotetext{
* Assist. Prof., Marmara University, Faculty of Arts and Sciences, Department of History, Göztepe/Kadıköy, İstanbul. E-mail: cifciali1@gmail.com. ORCID: 0000-0002-1404-9820

** This research was supported by a Strategic Research Initiative Study Grants from the British Institute at Ankara for a project called 'Sakçagözü in Context: Garstang's 1908-1911 Excavations Revisited' between 2016 and 2017.

(Makale Gönderim Tarihi: 20.06.2019 - Makale Kabul Tarihi: 07.11.2019)
} 


\section{Ali ÇIFÇI}

\section{Introduction}

John Garstang (b.1876 - d.1956), was one of the first person to study the Hittite civilization, came to Turkey for the first time in 1904 to explore Phrygian settlements in Western Anatolia. ${ }^{1} \mathrm{He}$ is known to have visited Gordion during this trip. He also carried out a surface survey in Anatolia in $1907 .{ }^{2} \mathrm{He}$ is, however, largely known for his archaeological excavations at Sakçegözü and his research into the Hittite kingdom. ${ }^{3}$ Encouraged by Archibald Sayce (b.1846 - d.1933), Assyriology professor at Oxford University, he was granted a permit by Osman Hamdi Bey, the director of the Imperial Museum (Müze-i Hümayun, Istanbul Archaeological Museums) in 1907 to excavate Boğazköy. Upon arriving in Turkey, however, he was informed that his permit had been revoked ${ }^{4}$ and given instead to the German Hugo Winckler.

Disappointed about losing his excavation permit, Garstang travelled to Central and Southeast Anatolia and Northern Syria, documenting settlements along the way. ${ }^{5}$ Garstang started his journey in Ankara and began by visiting Boğazköy. During this two-month Anatolian journey in 1907, he was accompanied by his personal photographer, the German Horst Schliephack, who photographed the numerous settlements they visited. On 4 July 1907, he arrived in Sakçagözü and examined the höyük and the reliefs situated on its surface. ${ }^{6} \mathrm{He}$ also took a photograph of one of these reliefs. The general consensus regarding Garstang's Anatolian journey was that he travelled in order to locate a Hittite settlement that he and his team could excavate, and came to Sakçagözü as a result.

It is understood, however, that Garstang began corresponding with the Ottoman Empire about excavating Sakçagözü earlier, in December $1906 .^{7}$ A map in the Ottoman archives shows Sakçagözü and its vicinity, which must have been sent by Garstang to support his proposed excavation. The date 19 June 1905 is written on this map, prepared either by Garstang himself or by Sir Edwin Pears (b.1835 - d.1919), member of the British Consulate who supported him on his Anatolian travels. ${ }^{8}$ It appears, therefore, that Garstang was preparing

\footnotetext{
1 In addition to his archaeological work in Anatolia, he played a significant role in the establishment of the British Institute of Archaeology at Ankara (1948) and the Institute of Archaeology at the University of Liverpool (1904), as well as the journal University of Liverpool Annals of Archaeology and Anthropology.

${ }^{2}$ Garstang 1908a.

${ }^{3}$ Garstang 1910, 1929; Garstang and Gurney 1959.

${ }^{4}$ Greaves and Rutland 2015, p. 33 .

${ }^{5}$ Greaves and Rutland 2015, p. 40.

${ }^{6}$ Garstang 1908a, p. 3.

${ }^{7}$ Genç 2015, p. 104-105.

${ }^{8}$ Genç 2015: p. 106, Fig 5.1 no. 5.
} 
to work at Sakçagözü long before he came to Istanbul to excavate Boğazköy. According to Garstang's own account, Osman Hamdi Bey encouraged him to excavate at Sakçagözü. ${ }^{9}$ Garstang appears to have paid great attention to forming good relations with Osman Hamdi Bey following the revoking of his permit to excavate at Boğazköy. Shortly before Garstang received his excavation permit in 1907, Osman Hamdi Bey's painting 'Young Emir Studying' was purchased for the Liverpool Art Gallery (Walker Art Gallery) ${ }^{10}$ upon the recommendation of the chancellor of the University of Liverpool (Sir Francis Chatillon Danson). ${ }^{11}$ It appears, therefore, that Garstang planned his 1907 trip well in advance and with the intention to include Sakçagözü.

Mrs. Scott-Stevenson, during her visit to Sakçagözü in 1881, stated that there were three reliefs on the wall of one of the houses there. ${ }^{12}$ These threepiece basalt orthostats depicting a lion hunt were taken to the Pergamon Museum in Berlin by the Germans Carl Humann and Otto Puchstein during a visit to the site of Zincirli in $1890 .{ }^{13}$ Humann and Puchstein also published drawings of three relief fragments on and around the höyük. The Germans are understood to have applied for a separate permit to dig Sakçagözü during their Zincirli excavations. ${ }^{14}$ Garstang must have acted before the Germans to excavate there -he got a permit towards mid-1908, after a year and a half of lobbying.

This study explores the two seasons of excavations carried out at Sakçagözü in 1908 and 1911. Except for two short preliminary reports ${ }^{15}$ and a short review ${ }^{16}$, information on Garstang's work on the Sakçagözü excavations are scarce. Against this background, this study aims to assess the Sakçagözü excavations based on documents handwritten by John Garstang himself, as well as excavation photographs located in the Garstang Museum of Archaeology at the University of Liverpool, and excavation material stored in the Istanbul Archaeological Museums. The reasons behind the excavation at Sakçagözü, attempts to take the orthostats out of Turkey, and Garstang's relationship with Osman Hamdi Bey will also be discussed below.

\footnotetext{
${ }^{9}$ Garstang 1908b, p. 97-98.

${ }^{10}$ Rutland 2014, p. 57; Pears 1916, p. 177.

${ }^{11}$ Osman Hamdi Bey's paintings were purchased previously in the same way by the French, through the efforts of Leon Heurzey, Curator of Oriental Antiquities at the Louvre, and by the University of Pennsylvania in 1893 (Holod and Ousterhou 2011: 30-31).

${ }^{12}$ Scott-Stevenson also mentions that these reliefs were brought from Coba Höyük (Yabba Houagu) by the son of the owner of the house and that there were more reliefs on the höyük (ScottStevenson 1881, p. 88-89).

${ }^{13}$ Humann and Puchstein 1890.

${ }^{14}$ The relevant document dates to 3 December 1907 (BEO.003183/23865).

${ }^{15}$ Garstang 1908b, 1913; Genç 2015, p. 108.

${ }^{16}$ Garstang et al. 1937.
} 


\section{Location of Sakçagözü (Coba Höyük)}

Sakçagözü is approximately $3 \mathrm{~km}$ west of its namesake settlement, in the Nurdağı district of Gaziantep province, about $21 \mathrm{~km}$ northeast of Zincirli Höyük (Fig. 1). ${ }^{17}$ The Sakçagözü Plain, a continuation of the Islahiye Plain, spreads in the southwest-northeast direction. The Amanos Mountains are to the west of the plain while to its east are the Kartal Mountains.

Coba Höyük, named "Höyük A" by Garstang, was approximately 140x90 $\mathrm{m}$ wide with a height ranging between $10-11 \mathrm{~m}^{18}$, but today it has almost totally disappeared and the area is being used for agricultural purposes. Garstang refers to five mounds in the Sakçagözü Plain, the smallest of which, he states, was Coba Höyük. Immediately to the west of Coba Höyük is the Songurus Höyük (Höyük B) and to the northwest is Keferdiz Höyük (Höyük C). The plain is rich in water sources and fertile agricultural fields. A lake and a marsh are visible immediately north of Songurus Höyük on the map where Garstang showed the location of the plain and ancient settlements in the region. ${ }^{19}$

\section{Coba Höyük Excavation}

Coba Höyük is also referred to as Sakçagözü, Sakje-Geuzi or Jobba Eyuk in archaeological literature. The höyük's small size and the presence of two orthostats made it an obvious choice for the first excavations. This took place in 1908 with further excavations carried out two years later in $1911 .{ }^{20}$ Soundings were also made at other mounds in the Sakçagözü Plain including Songurus and Keferdiz. Garstang suspended the excavation due to unrest in the Maraş and Antep regions in 1909 and $1910 .^{21}$ Much later in 1949 the British Institute of Archaeology at Ankara carried out a second excavation at Coba Höyük. ${ }^{22}$

These excavations demonstrated that Coba Höyük was settled uninterruptedly from the Chalcolithic until the Roman period. Of the 11 identified layers, IX. and X. contain the Neo-Hittite palace complex, which was surrounded by walls and had a bit hilani structure decorated with reliefs.

The walls that enclosed Neo-Hittite palace complex follow a regular plan except for its northwest corner where the slope slightly inwards due to the

\footnotetext{
${ }^{17}$ Çifçi 2016, p. 24.

${ }^{18}$ Garstang 1908b, p. 100-101; 1913, p. 68.

${ }^{19}$ Garstang 1908b, Pl. XXXIII.

${ }^{20}$ Garstang reached Sakçagözü after a four-day journey in August 1908, passing through Tarsus, Adana and Gâvur (Nur) Mountains. He states that they set up camp on the skirts of Kurt Mountain to protect themselves from humidity and malaria (Garstang 1908b, p. 97-98) and that a few days after arriving at Sakçagözü they began excavating with about 100 workers.

${ }^{21}$ Rutland 2014, p. 58; Genç 2015, p. 109.

${ }^{22}$ Taylor et al. 1950, pp. 53-138.
} 
terrain (Fig. 2). The main city walls are $3 \mathrm{~m}$ thick, strengthened by quadrangular external buttresses at $4 \mathrm{~m}$ intervals. ${ }^{23}$ The distance between the buttresses is narrower where the mound is more inclined. The corner walls of the palace are similarly supported by buttresses. Garstang states that the palace building was surrounded by a wall, the remains of which could be observed around the mound. ${ }^{24}$ The excavation reports, however, contain no information about this wall.

The entrance of the palace, which had a single main gate, was to the southwest. The gate was flanked by two small towers, and its exterior and interior surfaces were decorated with reliefs. ${ }^{25}$ The area of the gate was affected by erosion and therefore severely damaged, resulting in the dislocation of the reliefs. The gate was decorated with orthostats similar to those previously taken to Berlin -the lion hunt scene (Fig. 4) - as well as with various other reliefs found on the mound during excavations.

The excavation plan shows three successive small rooms to the left of the main gate and a large courtyard reaching the bit hilani structure on the right. The floor of the large area that spans between the bit hilani structure and the entrance gate is made of cobbles. This cobbled path does not continue as far as the entrance gate. The cobbled pavement ends at a place covered with wide and smooth stone slabs - not annotated on the plan- before it reaches the entrance.

The bit hilani structure covering approximately $22 \mathrm{~m}^{2}$ (Fig. 2), also named the portico building, was unearthed at the northeast corner of the palace complex. $^{26}$ This building, defined as a colonnaded portico or bit hilani and widely used in Southeast Anatolian and Northern Syrian palace architecture, was discovered in situ at Coba Höyük. The floor of this portico was covered with large stone slabs as well as 14 orthostats that depict the same composition on their exterior and interior faces.

Two lions, their heads towards the entrance gate, flanked the interior of the entrance gate (Fig. 3 and 5). The exterior is flanked by two orthostats depicting two griffin demon (Fig. 6) looking towards the gate as well as two divine figures on either side of a tree of life (Fig. 7), which seem to have been placed inside a frame. Immediately behind the gate lions, in the interior, are two reliefs of a sphinx (Fig. 8) and king (Fig. 9). The king relief on the right-hand side is seriously damaged leaving only its left foot and some of its body visible. Again, two orthostats were found in situ to the west of the entrance gate, which shows two male palace officials in a walking position (Fig. 10). Only fragments

\footnotetext{
${ }^{23}$ Garstang 1908b, p. 103, 1913, p. 68 Pl. III.

${ }^{24}$ Garstang 1913, p. 65.

${ }^{25}$ Garstang 1913, p. 68.

${ }^{26}$ Garstang 1913, p. 69.
} 
of the eastern version of the orthostats were discovered (SG-050, Sg-051, SG052). Two sphinxes placed in the middle of the entrance gate was a lion column-base decorated with linear decorations (Fig. 11). The front part of the lion sphinx base on the right-hand side is broken.

The entrance where these reliefs are located opens to a hall, which gives access to other rooms to the east, west and north (Fig. 2). The eastern door leads to an elevated room (I) through two steps decorated with rosettes (SG-075, SG076, SG-077, SG-078, SG-079). Adjacent to this room and to the main wall is a space without a door (II). To the right of the entrance and on one side of the hall are two doors leading to the rooms in front (III-IV) adjacent to the main wall. Opposite the main entrance is a door leading to a big hall $(\mathrm{V})$ and a second room shown without a door on the excavation plan (VI). The door opening towards the west from the entrance hall initially leads to a small room (VII) and then to a courtyard paved with cobbles (VIII), inside which there is a staircase made of very smooth stones leading to the exterior walls of the palace. Garstang refers to a gap between the exterior wall of the palace and the walls of internal rooms to which this staircase provided access. ${ }^{27}$ The photographs (SG-0189, SG0190, SG-0191) in Garstang's archive, however, suggest that this neat staircase, of which about 10 steps can be seen clearly, might have been constructed to reach an upper floor or the buttresses supporting the exterior walls of the palace. A sewage system constructed of very smooth stones was also unearthed on the floor of this room (SG-0193). A second sewage system was discovered to the left of the palace entrance, again constructed of very smooth stones.

In addition to the architectural remains and reliefs, various small finds were also unearthed. The report of the 1908 season, for example, refers to the discovery of three seals in the bit-hilani building. ${ }^{28}$ The report of the 1911 season notes various finds including seals, seal impressions, Hittite hieroglyphs and inscribed seals, as well as a stone with marks on it $^{29}$ but does not provide any visual data or information. Indeed, there is no trace of these finds either in Istanbul Archaeological Museums or in the Garstang Museum of Archaeology. A letter preserved in the latter institution, however, mentions two small boxes, one of which held small finds discovered during the excavation. Garstang sent these to Osman Hamdi Bey to ask for his permission to take them out of Turkey. Therefore, he must have somehow taken the small finds of the 1908 season. There is no documentary material or archaeological artefacts, however, regarding the excavations in 1911.

\footnotetext{
${ }^{27}$ Garstang 1913, p. 69.

${ }^{28}$ Garstang 1908b, p. 107, Fig. XLIX.

${ }^{29}$ Garstang 1913, p. 71.
} 


\section{How the Excavated Reliefs Stayed in Turkey}

To finance his archaeological excavations Garstang established committees, which he named 'union's, with Liverpool dignitaries. These colonialist committees considered their own financial gains in supporting the excavation, which meant that their funding was conditional on Garstang sourcing them ancient artefacts for their private collections. This is why Garstang's excavations in Egypt were primarily focused on the discovery of artefacts, which he used to please and reward these investors, rather than any scientific aims. ${ }^{30}$ Garstang's main priority, therefore, turned into artefact collection and their transport to Britain.

One of the reasons that led Garstang to excavate in Sakçagözü must have been the existence of reliefs on the surface, which had been known for some time, and the possibility of further finds during his excavation. Indeed, in Coba Höyük he discovered the in-situ continuation of the surface reliefs as well as numerous small finds (Fig. 3). It is most likely that the reliefs were not taken to Britain due to their heavy weight and rough workmanship. Garstang mentions this in a letter to Pears on 29 October 1908. In the letter, which is in the collection of Garstang Museum of Archaeology, he notes that the sculptures unearthed during the excavations were very heavy but if he was provided with the necessary permits and replicas of five reliefs, he can transport them to Istanbul.

Another letter Garstang sent to Pears, dated 9 August 1909, explains that the two met in London in July 1909 and discussed how they could negotiate with Osman Hamdi Bey about the artefacts found in Sakçagözü. In this letter, Garstang states that he will meet with Osman Hamdi Bey in Oxford and, if possible, he would like to take him to the House of Commons. In the same letter, he says that he will make a division of archaeological artefacts of Sakçagözü and will note those he would like to take with him and those that should stay in the museum in Istanbul. He states that he will not be greedy during this process.

Foreign archaeologists who wished to excavate within the Ottoman Empire and to export archaeological finds strived to establish good relations with Osman Hamdi Bey. ${ }^{31}$ This was because the 1884 Ottoman Antiquities Regulation (Asar-ı Atika Nizamnamesi) prohibited the export of archaeological artefacts, therefore, foreigners tried to influence Osman Hamdi Bey by purchasing his paintings and giving him honorary degrees. ${ }^{32}$ In the same letter,

\footnotetext{
${ }^{30}$ Freeman 2015, p. 46.

${ }^{31}$ Holod and Ousterhout 2011, pp. 30-31.

${ }^{32}$ Sayce 1923, p. 327-328; Holod and Ousterhout 2011, p. 30-31; Alaura 2017.
} 
Garstang states that he will try to arrange an honorary title for Osman Hamdi Bey from the University of Liverpool. Osman Hamdi Bey did indeed receive such a title (Honorary Doctorate in Law) from Oxford University in 1913 with the initiatives of Sir Arthur Evans, David G. Hogarth and Sir William Ramsay. ${ }^{33}$ The University of Pennsylvania had given him an honorary degree previously. ${ }^{34}$ These titles must have been very precious for Osman Hamdi Bey -in fact, Pears notes that Osman Hamdi Bey considered his honorary degree from Oxford as the most valuable title he had ever been given. ${ }^{35}$

Despite these efforts, however, Garstang was unsuccessful in retrieving artefacts from Coba Höyük and he reburied the orthostats. These were later unearthed in 1939 and transported to Ankara and put on display in the Museum of Anatolian Civilizations. ${ }^{36}$ Other than various pottery and metal fragments and spindle whorls, there are, unfortunately, no other small finds from Sakçagözü in the Istanbul Archaeological Museums. It is likely that Garstang took all of the small finds with him to Britain.

\section{Dating of the Reliefs}

The whereabouts and details of the seals, seal impressions and Hittite hieroglyph inscribed seals noted in the excavation reports published in 1908 and 1911 are unknown. In their absence, the Neo-Hittite name of Coba Höyük and the dates of Neo-Hittite levels and buildings can only be ascertained by understanding the building techniques, style and subjects of the reliefs in the palace complex.

Two types of basalt reliefs, made at different times, but dating to the NeoHittite period were discovered at the entrances of the palace and the bit hilani building. They are located within the boundaries of the Kingdom of Sam'al $\left(10^{\text {th }}-7^{\text {th }}\right.$ centuries BC), whose capital was Zincirli Höyük. ${ }^{37}$ It was suggested, therefore, that Sakçagözü (Coba) could be the city of Lutibu, - according to the Assyrian king Shalmaneser III $^{38}(858-824$ BC), the city was under the rule of

\footnotetext{
${ }^{33}$ Pears 1916, p. 177.

${ }^{34}$ Holod and Ousterhou 2011, p. 32.

${ }^{35}$ Pears 1916, p. 177.

${ }^{36}$ Güterbock and Özgüç 1946, pp. 42-44; Taylor et al. 1950, pp. 53-54.

37 The Kingdom of Sam'al was destroyed in 712 BC by Sargon II, the Assyrian king. Archaeological excavations at Zincirli Höyük, which is $21 \mathrm{~km}$ southwest of Sakçagözü, were carried out in 1888 and 1902 by Carl Humann and Robert Koldewey, and later by Felix von Luschan (Luschan 1893).

${ }^{38}$ After his departure from Gurgum (Maraş) in $858 \mathrm{BC}$, Shalmaneser III is known to have fought against a Neo-Hittite coalition consisting of Carcamesh, Bit-Adini and Pattin in the city of Lutibu, the royal city of Haianu, king of Sam'al (Grayson 1996, A.0.102.1, 53-64'a).
} 
Haiianu $^{39}$, king of Sam'al in 858 BC. $^{40}$ Although the artefacts found at Sakçagözü were carved in the Aramean style, the orthostats of Zincirli are slightly different in terms of their iconographies and styles, and show Assyrian influence. ${ }^{41}$ Again, despite strong Assyrian influence in both groups of artefacts, their building techniques, subject matters and styles indicate different time periods.

For example, the lion hunt scene (Fig. 4), which stood at the palace gate, as well as fragments of a second lion hunt scene and a fragment of a lion's body date to the first half of $8^{\text {th }}$ century BC. ${ }^{42}$ The lion hunt scene spreads over three orthostats. There are two male figures in armour inside a chariot, one of whom is steering the horses while the other is depicted firing an arrow. A sun disk is visible immediately on top of the figures inside the chariot. Despite its similarities to chariots dating to the Assyria king Shalmaneser III, with its crossfixed arrows, spears and the lion head decorating the back of the chariot ${ }^{43}$, its eight-spoked wheels shows similarities with the period of Tiglath-pileser III $(744-727 \mathrm{BC}) .^{44}$ The central figure is shown with a spear in his left hand, with which he stabs the lion, and an axe in his raised right hand. The figure on the third panel is depicted with a spear stabbed in the lion's forehead. This last figure can be distinguished from the other figures through its Assyrian-style helmet. The gap on the right-hand side of the second and third panels on which the hunting scene is depicted is filled with four rosettes. The helmeted hunter and the two figures at the front inside the chariot are depicted with long beards and curled hair touching the back of their necks. The hair and beard styles show close similarities with the Aramean style reliefs and mainly indicate to the mid$8^{\text {th }}$ century $\mathrm{BC} .^{45}$ The figure on the middle panel, on the other hand, is shown without a beard.

The basalt reliefs found in situ in the bit hilani building at Coba Höyük are dated to a much later period owing to their styles and building techniques. ${ }^{46}$ The orthostats in particular, as well as the king relief $(90 \mathrm{~cm} \times 50 \mathrm{~cm})$ behind the gate lions (Fig. 9) and sphinxes in the interior of the decorated entrance area

\footnotetext{
${ }^{39}$ Sader 1987, p. 173 no. 57; Lipinski 2000, p. 237.

${ }^{40}$ Assyrian written documents regarding Lutibu, identified as Coba Höyük, date to $9^{\text {th }}$ century $\mathrm{BC}$, however, the palace complex discovered during the excavations is dated to the $8^{\text {th }}$ century BC. Therefore, it is highly unlikely that the Neo-Hittite settlement unearthed at Coba Höyük was the city of Lutibu.

${ }^{41}$ Ussishkin 1966, p. 18; Darga 1992, p. 300.

${ }^{42}$ Ussishkin 1966, p. 18.

${ }^{43}$ King 1915, Pl. LIV-LIX.

${ }^{44}$ Barnett and Falkner 1962, Pl. 42, 44; Ussishkin 1966, p. 21; Darga 1992, p. 300.

${ }^{45}$ Ussishkin 1966, p. 19, Fig. 3.

${ }^{46}$ Ussishkin 1966, p. 18; Landsberger 1948, pp. 71-75; Güterbock 1961, pp. 49-50.
} 
(Fig. 8), strongly suggest this dating. The king figure at Coba Höyük and the sculpture in Arslantepe-Malatya, discovered buried under the courtyard of the lion gate, show close similarities. ${ }^{47}$ The hair of both figures, for example, is carved in the Aramean style with wavy hair that ends with curls at the back of the neck. The beards are illustrated with spiral curls. Both figures have the royal symbol of lotus in their right hands while with their left hands they hold their robes, which are draped over their left shoulders like shawls. Similar to the sculpture in Arslantepe, the figure in the Coba relief is depicted with a long, tasselled robe reaching above his feet protected with thin sandals. These features reflect the Aramean fashion. The Coba Höyük relief and the king sculpture in Arslantepe show similarities not only in terms of style but also in terms of their clothes, the crown sitting on their heads, their posture and facial expressions. There are also similarities between the Coba Höyük king relief and the reliefs showing processions of men found in the Hilani III building at Zincirli. ${ }^{48}$ As with Arslantepe, features such as the hair, the pleats of the robe and the left hand holding the robe give the impression of the same workshop.

It has been suggested that the reliefs discovered in the bit hilani building dated to the period of Mutallu, the last king of Kummuh (710-709 BC). ${ }^{49}$ Sargon II, king of Assyria (721-705 BC) is known to have rewarded Mutallu with the lands of the kingdoms of Sam'al and Melid in return for his aid during the former's campaign against Tarhunazi, king of $\mathrm{Melid}^{50}$, in $712 \mathrm{BC} .{ }^{51}$ It has been suggested, therefore, that the king sculpture at Arslantepe and the king relief discovered in situ at the left entrance of the bit hilani building at Coba Höyük were made during the reign of Mutallu, king of Kummuh. ${ }^{52}$ In view of the style and building technique of the bit hilani reliefs at Coba Höyük, referred to above, Darga states that they may have been built between 730 and $700 \mathrm{BC}^{53}$, which corresponds to Mutallu's reign.

In the absence of written data, it is very difficult to ascertain by whom and when these Neo-Hittite buildings at Coba Höyük were constructed. The styles and building techniques of reliefs of the city walls and palace building unearthed at the höyük, however, indicate a slight difference in time periods. Therefore, it can be surmised that the reliefs at the entrance of the city gate are

\footnotetext{
${ }^{47}$ Orthmann 1971, Taf. 41 A/12.

${ }^{48}$ Orthmann 1971, Taf. 65.

${ }^{49}$ Ussishkin 1966, p. 18; Landsberger 1948, pp. 71-75; Güterbock 1961, pp. 49-50.

${ }^{50}$ Luckenbill 1989, p. 26, 27, 60.

${ }^{51}$ Sargon sent Mutallu to exile in $708 \mathrm{BC}$ on the grounds of unpaid taxes and turned his land into an Assyrian province (Luckenbill 1989, p., 41, 45 and 64).

${ }_{52}^{52}$ Landsberger 1948, p. 76-77; Güterbock 1961, p. 50; Lipinski 2000, p. 237.

${ }^{53}$ Darga 1992, p. 302.
} 
earlier than those at the palace building and that both groups date to the second half of the $8^{\text {th }}$ century BC.

\section{Conclusion}

Based on archival material, this study aimed to understand the professional approaches of foreign archaeologists working within the Ottoman Empire during the early $20^{\text {th }}$ century, their relations with the director of the Imperial Museum Osman Hamdi Bey, archaeological permit processes and the whereabouts of excavated finds. This article is significant also because it demonstrates the potential of archival research. Garstang has always been known to have excavated Sakçagözü because his permit for Boğazköy was revoked but this study has shown that he had in fact prepared to work at Sakçagözü much earlier.

Except for the orthostats with the Lion Hunt scene, which were taken to Germany by the excavators of Zincirli Höyük in the 1890s, the Coba Höyük reliefs remain in Turkey and most are exhibited at the Museum of Anatolian Civilizations in Ankara. There is, however, no information as to the whereabouts of the small finds (seals, seal impressions etc.) discovered during the excavations, despite making brief references to their state and types in short reports written after the initial work. Garstang most likely took them with him to present to his financers as gifts. In the absence of written data, it is difficult to corroborate the hypotheses concerning Sakçagözü's identification Lutibu; however, the site must have been an important settlement within the Kingdom of Sam'al during the second half of the $8^{\text {th }}$ century BC. 
Ali ÇIFÇ亡

\section{BIBLIOGRAPHY}

Akurgal 1968

Alaura 2017

Çifçi 2016

Darga 1992

Freeman 2015

Garstang 1908a

Garstang 1908b

Garstang 1910

Garstang 1913

Garstang 1929 Garstang and Gurney 1959
Ekrem Akurgal, The Birth of the Greek Art: The Mediterranean and The Near East. (Translated by Wayne Dynes), Methuen: London.

S. Alaura, "Little by little the obscurity is being cleared away from the earlier history of Asia Minor. Searching for the Hittites, from Sayce to Winkler". The Discovery of an Anatolian Empire / Bir Anadolu Imparatorluğunun Keşfi. (eds.) M. Doğan-Alparslan, M. Alparslan and A. Schachner. İstanbul, Türk Eskiçağ Bilimleri Enstitüsü Yayınları: pp. 13-27.

R. D. Barnett and M. Falkner, The Sculptures of Assur-NasirApli II (883-859 BC) Tiglath-Pileser III (745-727 BC) Esarhaddon (681-669 BC) from the Central and South-West Palaces at Nimrud. London, The Trustees of the British Museum.

Ali Çifçi, "Sakçagözü in context: Garstang's 1908-1911 excavations revisited", Heritage Turkey 6: p. 24.

A. Muhibbe Darga, Hitit Sanatı. İstanbul, Akbank Kültür ve Sanat Hizmetleri.

P. Freeman, "John Garstang ve Yakındoğu Arkeolojisi" John Garstang's Footsteps Across Anatolia / Anadolu'da John Garstang'ın Ayak İzleri. (ed.) A. M. Greaves. İstanbul, Koç Üniversitesi Anadolu Medeniyetleri Araştırma Merkezi, pp. 45-60.

John Garstang, "Notes on a Journey through Asia Minor" University of Liverpool Annals of Archaeology and Anthropology 1, pp. 1-12.

John Garstang, "Excavations at Sakje-Geuzi, in North Syria: preliminary report for 1908" University of Liverpool Annals of Archaeology and Anthropology 1, pp. 98-117.

John Garstang, The land of the Hittites. London, Constable.

John Garstang, "Second Interim Report on the Excavations at Sakje-Geuzi in North Syria, 1911" University of Liverpool Annals of Archaeology and Anthropology 5, pp. 63-72.

John Garstang, The Hittite Empire. London, Constable.

John Garstang and Oliver R. Gurney, The Geography of the Hittite Empire. London: British Institute of Archaeology at Ankara. 
Garstang et. al. 1937 John Garstang, W. J. Phythian-Adams, V. Seton-Williams, "Third Report on the excavations at Sakje-Geuzi, 1908-1911" University of Liverpool Annals of Archaeology and Anthropology 24/3-4, pp. 119-140.

Genç 2015 B. Genç, “Osmanlı Arşivleri’nde John Garstang ve Sakçagözü” John Garstang's Footsteps Across Anatolia / Anadolu'da John Garstang'ın Ayak İzleri. (ed.) A. M. Greaves. İstanbul, Koç Üniversitesi Anadolu Medeniyetleri Araştırma Merkezi, pp. 103-114.

Grayson 1996 A. Kirk Grayson, Assyrian Rulers of the Early First Millennium BC II (858-745 BC), Toronto, University of Toronto Press.

Greaves and Rutland 2015

A. M. Greaves, and F. Rutland, "Garstang'ın Anadolu Yüzey Araştırması ve Hitit Ülkesi” John Garstang's Footsteps Across Anatolia / Anadolu'da John Garstang'ın Ayak Izleri. (ed.) A. M. Greaves. İstanbul, Koç Üniversitesi Anadolu Medeniyetleri Araştırma Merkezi, pp. 33-44.

Güterbock 1961 Hans Gustav Güterbock, "When Was the Late Hittite Palace at Sakçagözü Built”, Bulletin of the American Schools of Oriental Research 162, pp. 49-50.

Güterbock and Özgüç 1946

Hans Gustav Güterbock and Nimet Özgüç, Ankara Bedesteni’nde Bulunan Eti Müzesi Büyük Salonunun Kılavuzu. İstanbul, Milli Eğitim Basımevi.

Holod and Ousterhout 2011

R. Holod and R. Ousterhout, Osman Hamdi Bey \& The Americans. Archaeology, Diplomacy, Art / Osman Hamdi Bey \& Amerikalllar. Arkeoloji, Diplomasi, Sanat. İstanbul, Pera Müzesi.

Humann and Puchstein 1890

Karl Humann and Otto Puchstein, Reisen in Kleinasien und Nordsyrien. Berlin, Dietrich Reimer.

King 1915

L. W. King, Bronze Reliefs from the Gates of Shalmaneser King of Assyria B.C. 860-825, London, Oxford University Press.

Landsberger 1948. Benno Lansberger, Sam'al Karatepe Harabelerinin Keşfi ile ilgili Araştırmalar. Ankara, Türk Tarih Kurumu.

Lipiński 2000 E. Lipiński, The Aramaeans: Their Ancient History, Culture, Religion. (Orientalia Lovaniensia Analecta 100) Leuven, Peeters.

Luckenbill 1989 Daniel D. Luckenbill, Ancient Records of Assyria and Babylonia II, London, Histories \& Mysteries of Man. 


\section{Ali ÇIFÇI}

Luschan 1893

Felix von Luschan, Ausgrabungen in Sendschirli. I: Einleitung und Inschriften. Berlin, W. Spemann.

Orthmann, W. 1971. Untersuchungen zur späthethitischen Kunst. Bonn, Rudolf Habelt Verlag.

Pears, Sir E. 1916. Forty Years in Constantinople - The Recollections of Sir Edwin Pears 1873-1915, London, Herbert Jenkins.

Rutland, F. P. 2014. The Lost Gallery: John Garstang and Turkey - A Postcolonial Reading, University of Liverpool, School of Archaeology, Classics and Egyptology. Unpublished PhD.

Sader 1987

Sayce 1923

H. S. Sader, Les États Araméens de Syrie depuis leur fondation jusqu'à leur transformation en provinces Assyriennes, (Beiruter Texte und Studien 36) Wiesbaden, Franz Steiner.

Scott-Stevenson 1881 Archibald H. Sayce, Reminiscences. London, Macmillion.

M. Scott-Stevenson Our ride through Asia Minor, London, Chapman and Hill.

SG. 2010.

The photographic archive of excavations at Sakje Geuzi 19081911 Reference No: SG. The Garstang Museum of Archaeology, University of Liverpool: Liverpool.

Ussishkin 1966

David Ussishkin. "The Date of the Neo-Hittite Enclosure at Sakçagözü”, Bulletin of the American Schools of Oriental Research 181, pp. 15-23.

Taylor et. al. $1950 \quad$ J. du Plat Taylor, M. V. Seton Williams, and J. Waechter, "The Excavations at Sakce Gözü” Iraq 12/2, pp. 53-138. 
John Garstang and Sakçagözü Excavations (1908-1911)

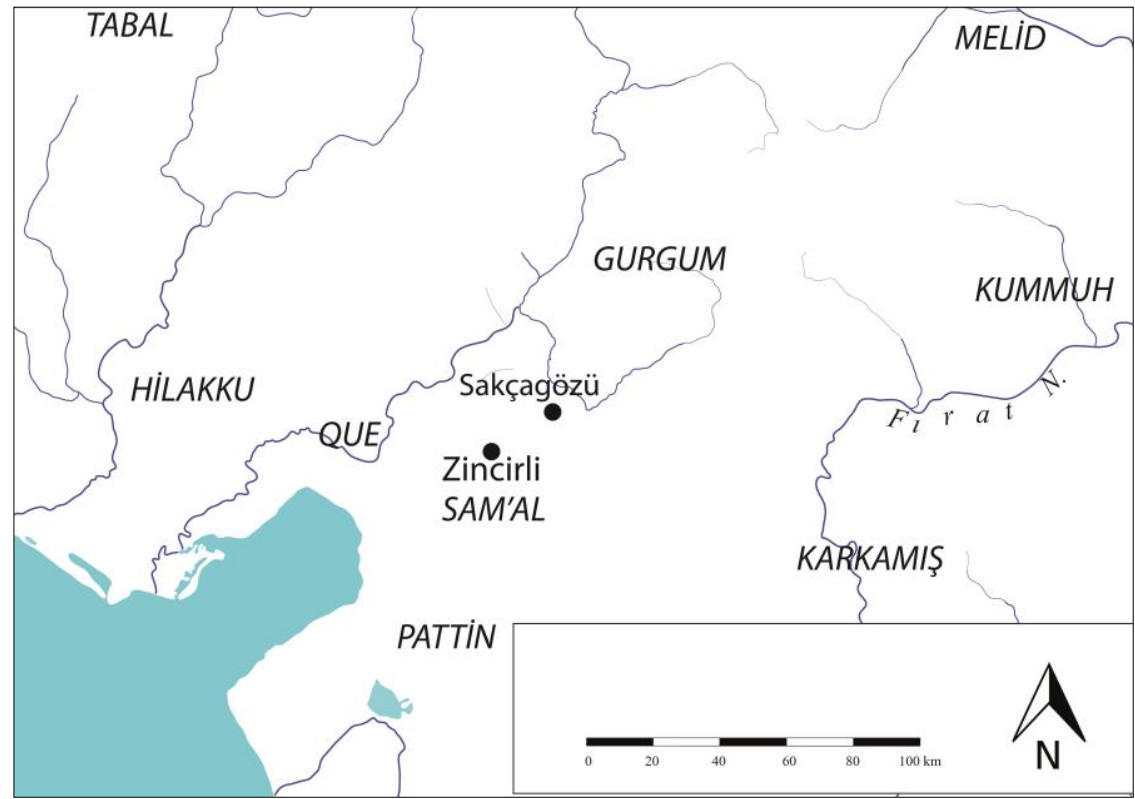

Fig. 1. Map of Cilicia with location of Sakçagözü (Coba) Höyük

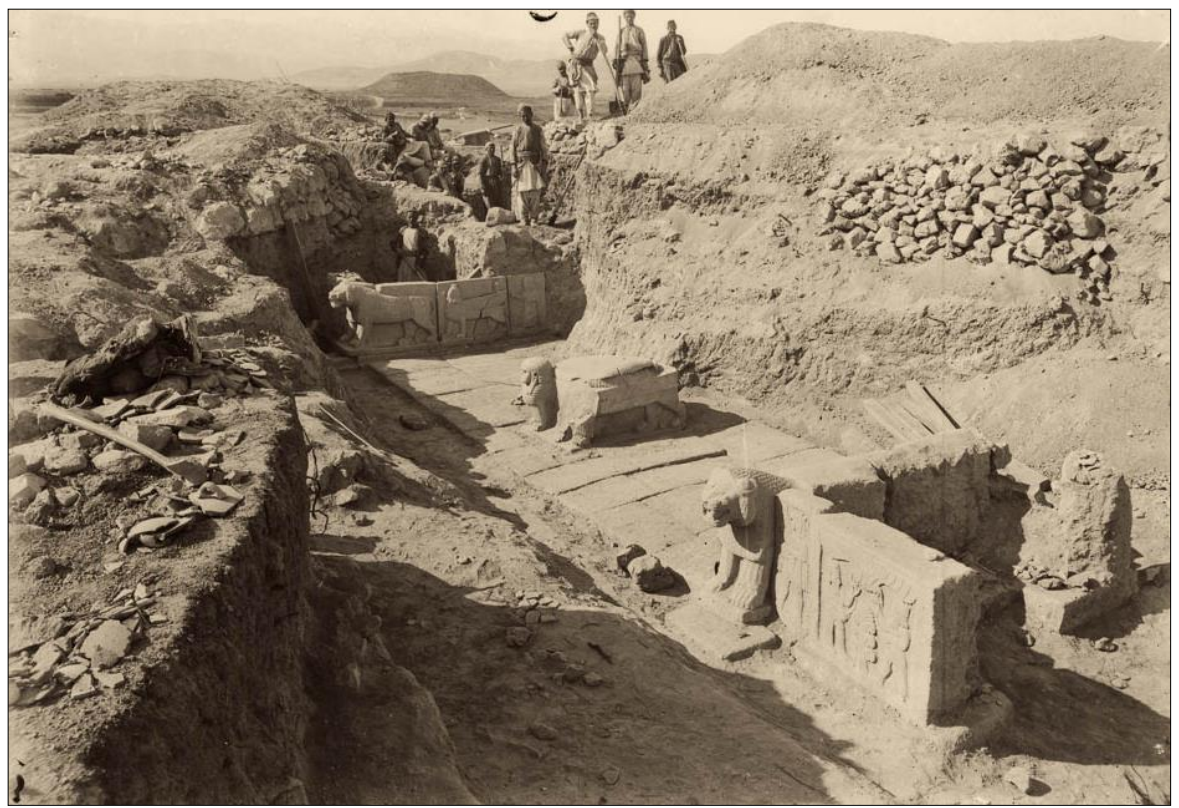

Fig. 3. Sakçagözü bit-hilani structure with basalt reliefs in situ (Courtesy of The Garstang Museum of Archaeology, University of Liverpool) 


\section{Ali ÇIFÇİ}

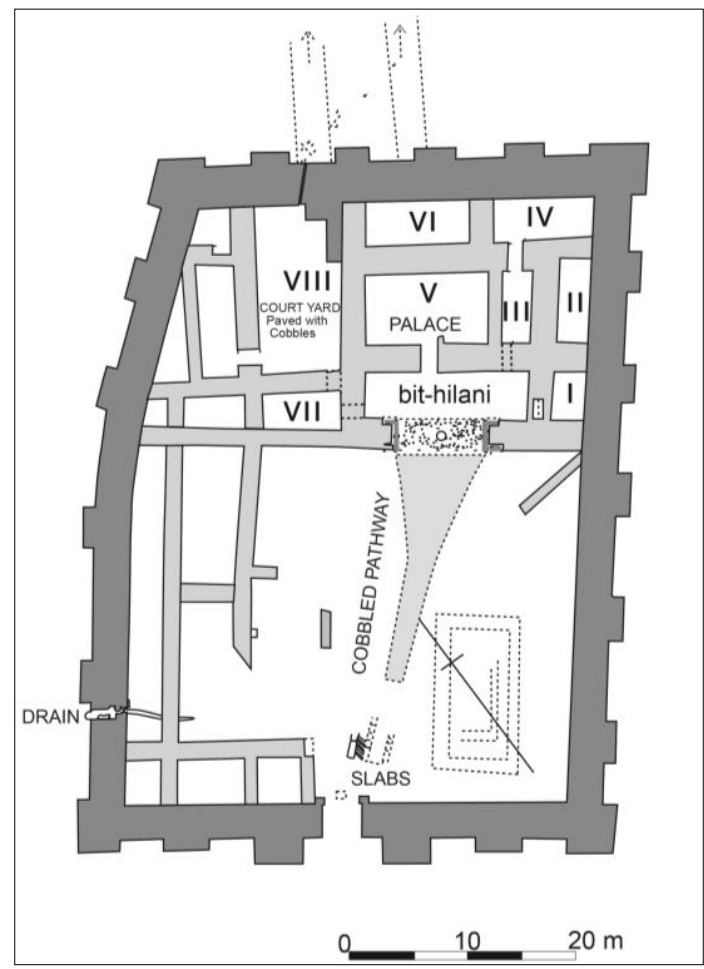

Fig. 2. Plan of Sakçagözü (After Garstang 1913, Pl. 3)

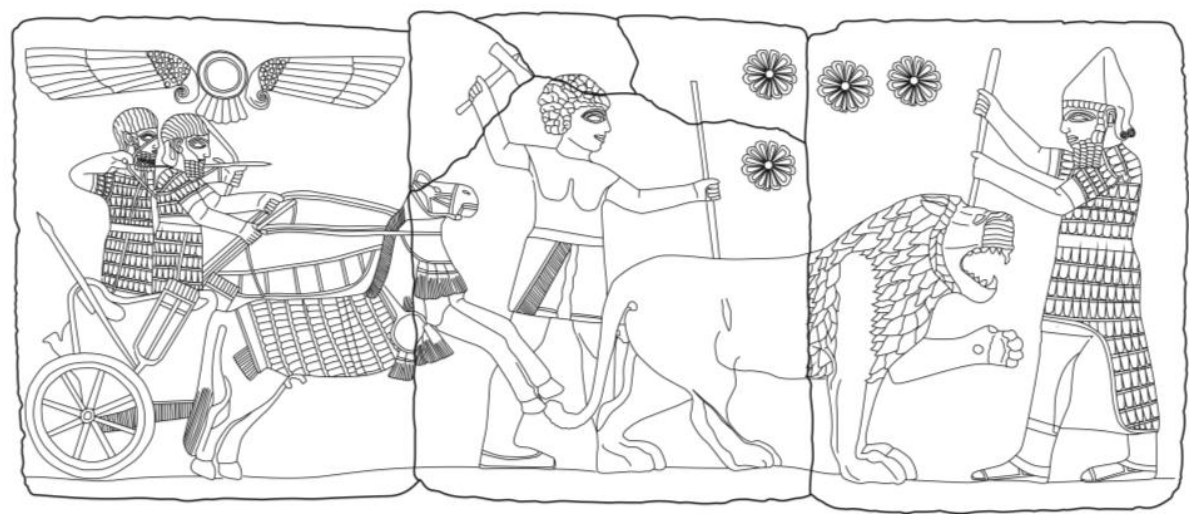

Fig. 4. The Lion Hunt relief (adapted from Akurgal 1968, Pl. 23b) 


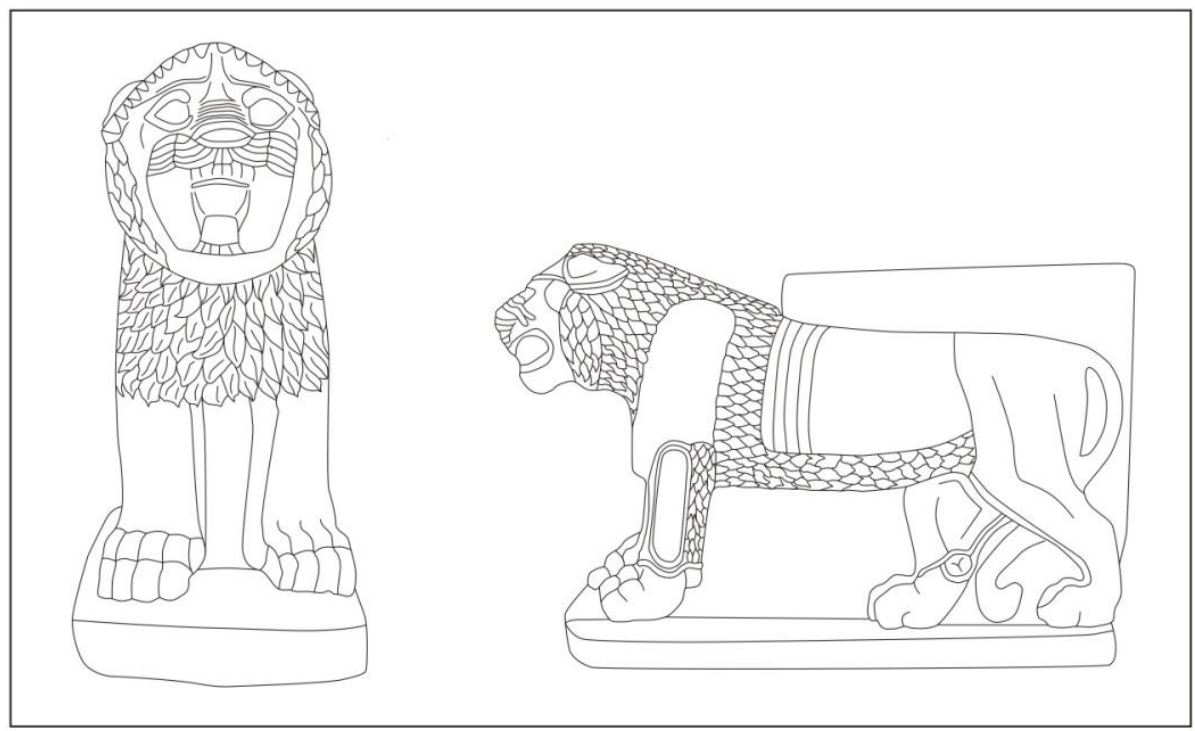

Fig. 5. Portal lion. ${ }^{54}$
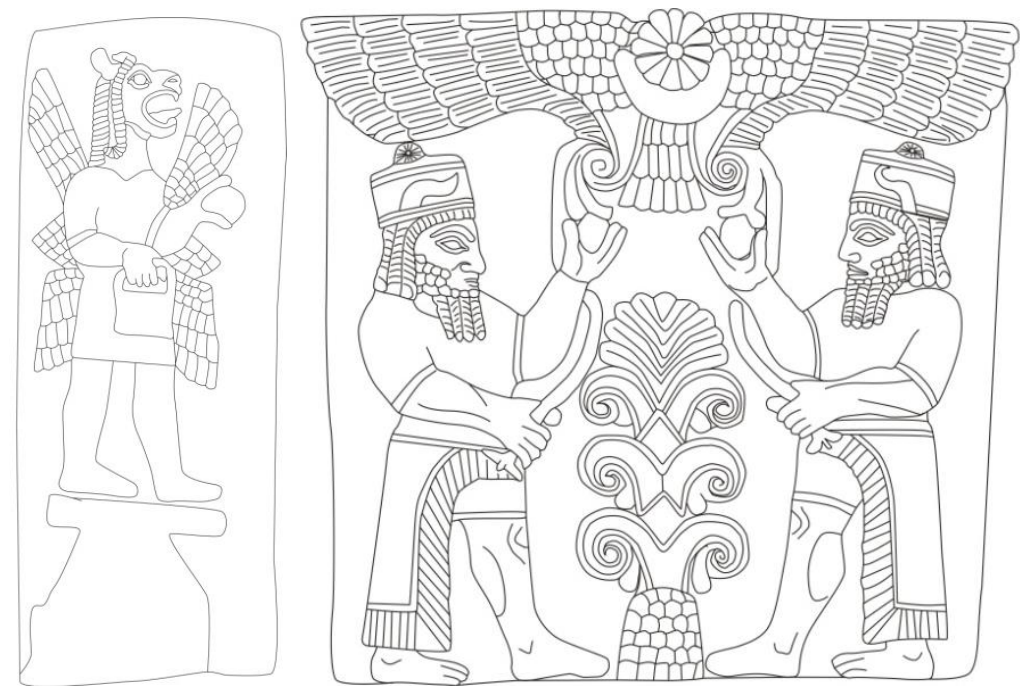

Fig. 6. Griffin demon. Fig. 7. Two Divine figures on either side of a tree of life.

\footnotetext{
${ }^{54}$ Figures 5-11 were drawn from Sakçagözü reliefs in Ankara (Courtesy of the Museum of Anatolian Civilization in Ankara).
} 
Ali ÇIFÇİ

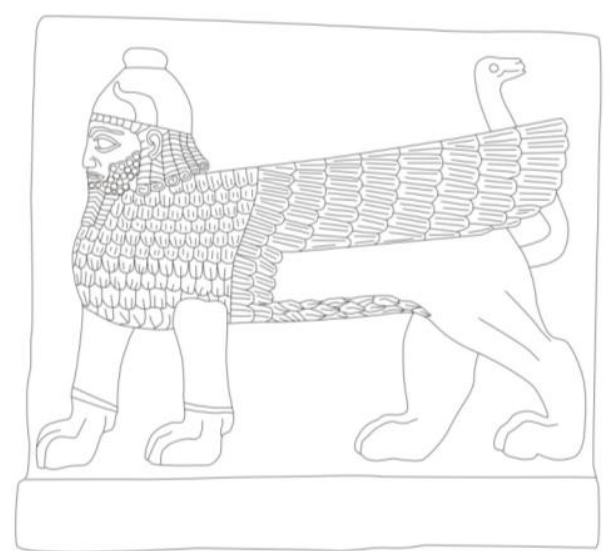

Fig. 8. Sphinx.

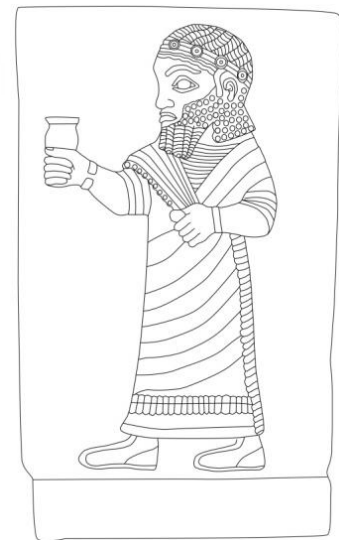

Fig. 9. The king relief.

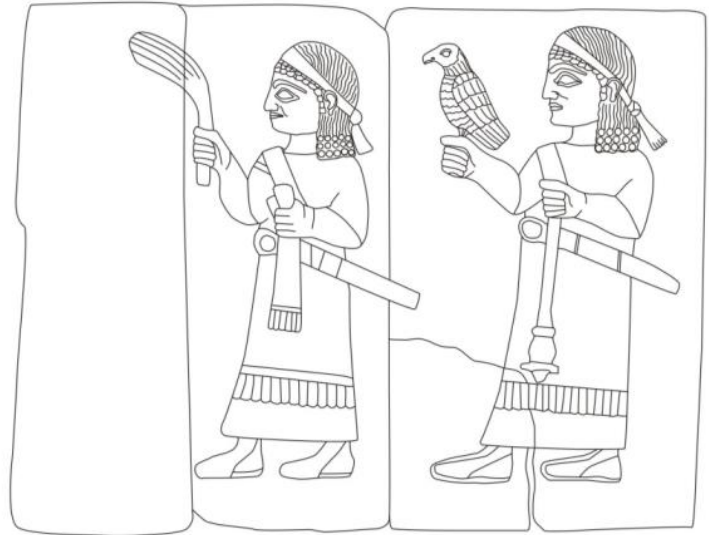

Fig. 10. Relief showing two male palace officials

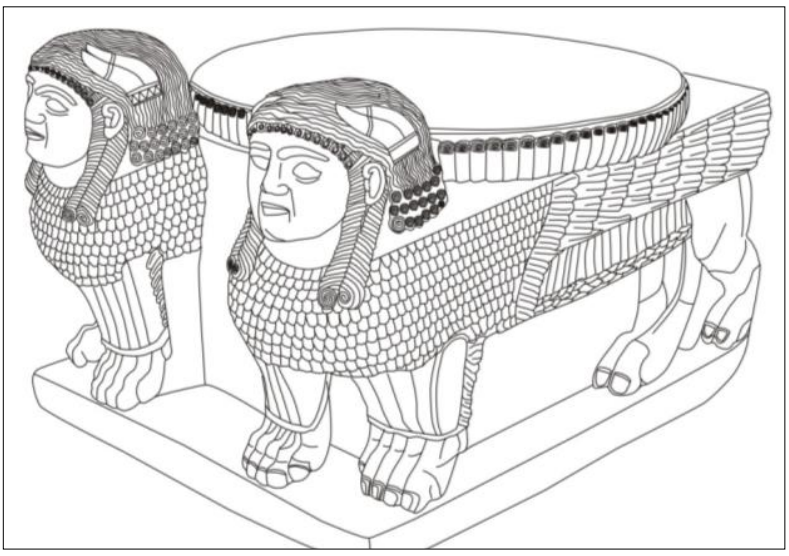

Fig. 11. Lion Column-base 